\title{
Wolf spider burrows from a modern saline sandflat in central Argentina: morphology, taphonomy and clues for recognition of fossil examples
}

\author{
Fatima Mendoza Belmontes ${ }^{\text {Corresp., }}{ }^{1}$, Ricardo N Melchor ${ }^{2}$, Luis N Piacentini ${ }^{3}$ \\ 1 UNLPam, FONCyT doctoral scholar, Santa Rosa, La Pampa, Argentina \\ 2 INCITAP- UNLPam, CONICET, Santa Rosa, La Pampa, Argentina \\ 3 Museo Argentino de Ciencias Naturales 'Bernardino Rivadavia', CONICET, Buenos Aires, Argentina \\ Corresponding Author: Fatima Mendoza Belmontes \\ Email address: famebel@exactas.unlpam.edu.ar
}

Pavocosa sp. (Lycosidae) burrows found in an open sparsely vegetated area on the edge of the Gran Salitral saline lake, in central Argentina, are described. Burrows were studied by capturing the occupant and casting them with dental plaster. The hosting sediments and vegetation were also characterized. Inhabited Pavocosa sp. burrows display distinctive features as open, cylindrical, nearly vertical, silk lined shafts about $120 \mathrm{~mm}$ long, subcircular entrances, a gradual downward widening, and a particularly distinctive surface ornamentation in the form of sets of two linear parallel marks at a high angle to the burrow axis. Instead, casts of vacated Pavocosa sp. burrows showed some disturbances caused either by the reoccupation by another organism or by predation of the dweller. Two morphologies are related to reoccupation of burrows: those with a structure in form of an "umbrella" and another with smaller excavations at the bottom of the burrow. Predation by small mammals produces funnel-shaped burrows. Both active and abandoned Pavocosa $\mathrm{sp}$. burrow casts are compared with existing ichnogenera and inorganic sedimentary structures, highlighting its distinction. It is argued that key features like the presence of a neck, a downward widening and the described surface texture will allow recognition of wolf spider burrows in the fossil record. However, the putative spider burrows described in the literature either lack the necessary preservational quality or does not show ornamentation similar to the modern wolf spider burrows. Fossil wolf spiders are recorded since the Paleogene (possibly Late Cretaceous), therefore Cenozoic continental rocks can contain wolf spider burrows awaiting recognition. In addition, the particular distribution of Pavocosa sp. in saline lakes may imply that this type of burrows is linked to saline environments. 


\section{Wolf spider burrows from a modern saline sandflat in central 2 Argentina: morphology, taphonomy and clues for recognition 3 of fossil examples}

4 Fatima Mendoza-Belmontes ${ }^{1}$, Ricardo N. Melchor ${ }^{2}$ and Luis N Piacentini ${ }^{3}$

$5 \quad{ }^{1}$ FONCyT doctoral scholar, UNLPam, Av. Uruguay 151, Santa Rosa, La Pampa, 6300, Argentina

62 INCITAP (CONICET and Universidad Nacional de La Pampa), Av. Uruguay 151, Santa Rosa, La Pampa,

7 6300, Argentina

$8{ }^{3}$ Museo Argentino de Ciencias Naturales 'Bernardino Rivadavia'-CONICET, Av. Ángel Gallardo 470,

9 C1405DJR, Buenos Aires, Argentina

11 Corresponding Author:

12 Fatima Mendoza-Belmontes ${ }^{1}$

13 Av. Uruguay 151, Santa Rosa, La Pampa, 6300, Argentina

14 Email address: famebel@exactas.unlpam.edu.ar

15

16

17 
19 ABSTRACT

20 Pavocosa sp. (Lycosidae) burrows found in an open sparsely vegetated area on the edge of the

21 Gran Salitral saline lake, in central Argentina, are described. Burrows were studied by capturing

22 the occupant and casting them with dental plaster. The hosting sediments and vegetation were

23 also characterized. Inhabited Pavocosa sp. burrows display distinctive features as open,

24 cylindrical, nearly vertical, silk lined shafts about $120 \mathrm{~mm}$ long, subcircular entrances, a gradual

25 downward widening, and a particularly distinctive surface ornamentation in the form of sets of

two linear parallel marks at a high angle to the burrow axis. Instead, casts of vacated Pavocosa

sp. burrows showed some disturbances caused either by the reoccupation by another organism or by predation of the dweller. Two morphologies are related to reoccupation of burrows: those with a structure in form of an "umbrella" and another with smaller excavations at the bottom of the burrow. Predation by small mammals produces funnel-shaped burrows. Both active and abandoned Pavocosa sp. burrow casts are compared with existing ichnogenera and inorganic sedimentary structures, highlighting its distinction. It is argued that key features like the presence of a neck, a downward widening and the described surface texture will allow recognition of wolf spider burrows in the fossil record. However, the putative spider burrows described in the literature either lack the necessary preservational quality or does not show ornamentation similar to the modern wolf spider burrows. Fossil wolf spiders are recorded since the Paleogene

37 (possibly Late Cretaceous), therefore Cenozoic continental rocks can contain wolf spider burrows awaiting recognition. In addition, the particular distribution of Pavocosa sp. in saline lakes may imply that this type of burrows is linked to saline environments. 
42 Araneae (recorded since the Devonian) is the most diverse order within arachnids with around

43 47,000 described extant species (World Spider Catalog, 2017). Due to striking adaptations such

44 as silk production and a complex behavior (e.g. construction of hunting webs), Araneae has

45 become a highly successful group that is present in almost all environments (Murphy et al.,

46 2006; Garrison et al., 2016). Burrow construction in spiders is considered a primary adaptation as

47 a retreat from high temperatures and dry air conditions typical of arid environments (e.g.,

48 Cloudsley-Thompson, 1983; Punzo, 2000). Important functions as dwelling, nesting, mating,

49 breeding, and foraging are also related to burrows (e.g., Marshall, 1996; Aisenberg, Viera \&

50 Costa, 2007; Hils \& Hembree, 2015; Uchman, Vrenozi \& Muceku, 2017).

51 In general, modern spider burrows consist of vertical or oblique, simple or branched forms,

52 sometimes with a terminal chamber, in some cases silk lined, and structures atop as trap doors or

53 a turret can be found (e.g., Ratcliffe \& Fagerstrom, 1980; Bryson, 1939; Hils \& Hembree, 2015;

54 Uchman, Vrenozi \& Muceku, 2017). Among the burrowing spiders, those of the wolf spiders

55 (Lycosidae) tend to produce a nearly vertical burrow with or without a terminal chamber in flat

56 terrain, whereas many trapdoor spider burrows (families Nemesiidae, Ctenizidae,

57 Antrodiaetidae) are at an oblique angle and located on inclined surfaces (Uchman, Vrenozi \&

58 Muceku, 2017). This simple morphology can be comparable to the ichnogenenera Skolithos

59 Hadelman, 1840 or Cylindricum Linck, 1949 (Smith et al., 2008; Hils \& Hembree, 2015;), the

60 Y-shaped forms to Psilonichnus Fürsich, 1981 (Uchman, Vrenozi \& Muceku, 2017), and those

61 with a terminal chamber to Macanopsis Macsotay, 1967 (Hasiotis, 2006; Mikuś \& Uchman,

62 2012; Hils \& Hembree, 2015; Uchman, Vrenozi \& Muceku, 2017).

63 Significant research related to burrow construction in wolf spiders has been made, but mainly

64 focused on biological and ecological aspects (e.g. Hancock, 1899; Marshall, 1996; Aisenberg, 
Viera \& Costa, 2007; Carrel, 2008; Suter, Stratton \& Miller, 2011; De Simone, Aisenberg \& Peretti, 2015; Foelix et al., 2016, 2017; Framenau \& Hudson, 2017). In addition to the pioneer contributions by Bryson (1939), Ahlbrandt et al. (1978), and Ratcliffe \& Fagerstrom (1980), recent neoichnological studies has paid attention to the morphology of spider burrows (Hils \& Hembree, 2015; Hembree, 2017; Uchman, Vrenozi \& Muceku, 2017). These studies rely essentially on the overall morphology as a clue for recognition of spider burrows in general, including those of Lycosidae.

Similarly, probable spider burrows in the fossil record are scarce and its identification was always based on general morphology. The oldest record is controversial and based on poorly preserved simple vertical hollows from the Eocene of northern France, first considered worm burrows (Polychaeta) and later assigned to trapdoor spiders, in both cases named using biological names for a trace fossil (see details in Dunlop \& Braddy, 2011). The same material was later incorrectly referred to Oichnus Bromley, 1981 by Dunlop \& Braddy (2011), an ichnogenus reserved for bioerosion structures on calcareous skeletons (Wisshak et al., 2015). Skolithos isp. 1 from the Mio-Pliocene fluvial sediments of Brazil was compared with Lycosidae burrows due to its overall morphology (Fernandes, Borghi \& Carvalho, 1992). Pleistocene and Holocene carbonate eolianites from Bahamas and Yucatán contains Skolithos linearis Haldeman, 1840 that were tentatively assigned to arachnids and/or insects (White \& Curran, 1988; Curran \& White, 1991, 2001). Finally, a burrow in Pleistocene clastic sediments of the Simpson Desert in Australia (Hasiotis, 2007), was attributed to wolf spiders.

The purposes of this work are 1) the identification of ichnological signatures of the burrows produced by Pavocosa sp. (Lycosidae) that may facilitate identification of wolf spider burrows in the fossil record, and 2) to discuss its environmental distribution. 


\section{Previous descriptions of modern wolf spider burrows}

90 The first work unequivocally related to burrows of wolf spiders was "The castle - building

91

92 spider" from Illinois (USA) published by Hancock (1899). This paper describes in detail the burrows produced by Geolycosa domifex Hancock, 1899 (=Lycosa domifex), explaining important aspects as materials and the methods of construction. Geolycosa domifex burrows are described as vertical shafts, unless obstacles cause some deviation (Fig. 1A). Ratcliffe \& Fagerstrom (1980), in his widely cited work on traces found in Holocene floodplains, described spider burrows in general (assigned to Ctenizidae, Antrodiaetidae, Theraphosidae and Lycosidae) as simple or branched tunnels, sometimes with side chambers that are separated of the main tunnel by hinged doors (Fig. 1B). Burrows of Geolycosa xera archboldi McCrone, 1963 and G. hubbelli Wallace 1942 from Florida, USA, are illustrated as vertical shafts showing a gradual transition between the shaft and the terminal chamber (Fig. 1C-D) (Carrel, 2008). Geolycosa missouriensis Banks, 1895 burrows from Mississippi, USA, are described as vertical forms, narrower at the surface and broader near the bottom, sometimes with a conspicuously enlarged chamber at the bottom (Fig. 1E) (Suter, Stratton \& Miller, 2011). Geolycosa sp. burrows from India, exhibited a contrasting morphology in comparison with previous records of wolf spiders. These burrows were complex with a U-shaped form, two chambers (located one at the entrance and the other at the end of the burrow), and shallow hollows described as drainages or prey traps (Fig. 1F) (Chikhale et al., 2013). Albín, Simó \& Aisenberg (2015), reported different burrow morphologies produced by Allocosa brasiliensis Petrunkevitch 1910 from Uruguay, linking these variations in the morphology to the development stage and sex of the spider that produce them. These authors described burrows with a simple vertical shaft and a terminal chamber produced by adults, shallow capsules by virgin females, and Y-shaped burrows by male juveniles (Fig. 
112 1G). Hils \& Hembree (2015), through experimental neoichnological studies, recorded four

113 burrow morphologies produced by Hogna lenta Hentz, 1844 (Lycosidae): vertical shafts, vertical

114 shafts with a terminal chamber, sub-vertical shafts, and Y-shaped burrows (Fig. 1H). Geolycosa

115 vultuosa Koch, 1838 burrows from Albania are characterized as vertical to subvertical, slightly

116 curved or straight shafts with a basal chamber, showing either a gradual transition between the

117 shaft and the basal chamber or a well delineated chamber (Vrenozi \& Uchman, 2015). In a

118 taxonomic revision of the halotolerant wolf spider genus Tetralycosa Roewer, 1960 (Framenau

119 \& Hudson, 2017); the burrows of three species (T. alteripa McKay 1976, T. williamsi Framenau

120 \& Hudson 2017, and T. eyrei Hickman 1944) were described. Tetralycosa burrows are vertical

121 shafts with an offset (a curvature) at mid-depth, which are later modified by backfilling the part

122 above the curvature and creating a new burrow oriented in the opposite direction (Fig. 1I)

123 (Framenau \& Hudson, 2017). Allocosa senex (Mello-Leitão, 1945) burrows from Uruguay are

124 also simple vertical shafts with a downward widening (Fig. 1J) (Foelix et al., 2017). Finally, the

125 burrows of Trochosa hispanica Simon, 1870 from Albania (Fig. 1K) were described as simple,

126 vertical shafts with a terminal chamber (Uchman, Vrenozi \& Muceku, 2017).

127 From the previous account, it is clear that the most common form in wolf-spider burrow are

128 almost vertical cylinders with a rounded end that increase progressively in width downward,

129 vertical shafts with a terminal chamber, and Y shaped burrows. Hasiotis (2006) also suggested

130 that horizontal burrows systems with a pustulose ornamentation are produced by spiders,

131 however, the illustrated burrow system (Hasiotis, 2002, p. 114, figure B) is typical of surface

132 burrows produced by Grillotalpidae (e.g., Chamberlain, 1975). Figure 1 also highlight that the

133 burrows produced under experimental conditions (Fig. 1H) contrast markedly with the remaining

134 ones excavated in natural conditions. 


\section{MATERIALS AND METHODS}

137 We studied burrows produced by Pavocosa sp. found on the edge of sparsely vegetated sandflat 138 of the Gran Salitral saline lake located in southwest La Pampa Province, Argentina $139\left(37^{\circ} 24^{\prime} 18.40^{\prime \prime} \mathrm{S}, 67^{\circ} 12^{\prime} 13.57^{\prime \prime} \mathrm{W}\right)$ (Fig. 2A-B). This saline lake is placed in the subregion of 140 alluvial plains of the Atuel-Salado rivers, characterized by a flat relief and sandy sediments, 141 under a semiarid climate and with halophyte vegetation (Fig. 2C) (INTA-UNLPam, 1980). The

142 Gran Salitral saline lake is the terminal part of an endorheic drainage system that occasionally 143 receives waters from the Atuel- Salado rivers. Modern brines exhibit a concentration ranging 144 from 213 to $252 \mathrm{~g} / \mathrm{l}$ and the near-surface sediments of the saline lake attest for hydrological

145 variations during the Holocene, including fluctuations in brine salinity and lake level (Melchor \& 146 Casadío, 2000). The mean monthly temperature ranges between $6.9^{\circ} \mathrm{C}$ in July and $24.6{ }^{\circ} \mathrm{C}$ in 147 January, and the mean annual precipitation is $340 \mathrm{~mm}$, in both cases for the period 1961-1980 148 (INTA-UNLPam, 1980).

149 Observations were conducted during three field trips in October-2016 (early spring, mean 150 monthly temperature for $2016: 15.4^{\circ} \mathrm{C}$, and the total monthly precipitation was $140 \mathrm{~mm}$ ), 151 December-2016 (late spring, mean monthly temperature for $2016: 23.1{ }^{\circ} \mathrm{C}$, with no 152 precipitations) and February-2017 (summer, mean monthly temperature for $2017: 24.7^{\circ} \mathrm{C}$, and 153 precipitation was $22 \mathrm{~mm}$ ). Rain data was obtained from Policía de la Provincia de la Pampa 154 (http://www.policia.lapampa.gov.ar/contenidos/ver/lluvias); and temperature data from Servicio 155 Meteorológico Nacional (www.smn.gov.ar), in both cases for the nearby 25 de Mayo and Puelén 156 towns.

157 Sandflat sediments were logged in a shallow pit using standard sedimentological methods, and 158 samples were taken for grain size and carbonate content analysis. Carbonate content of sediment 
159 samples was estimated using the Digital Calcimeter "NETTO" that indicates the total percent 160 amount of calcium and magnesium carbonates. Grain size analyses of sediment samples were 161 obtained by a laser particle size counter Malvern Mastersizer 2000®, prior to elimination of 162 organic matter and carbonates, at the Laboratorio de Sedimentología of the Facultad de Ciencias 163 Exactas y Naturales, Universidad Nacional de La Pampa.

164 A total of nine burrows were casted using dental plaster and three spiders found inside the 165 burrows were collected for identification. Measurements on casts taken were the total length (L), 166 neck length (NL), the minimum (mD) and maximum diameter (MD), and the angle of inclination 167 (A); the measures of sets of surface ridges preserved on the cast, that are the length, the width, and the orientation in relation to the principal axis of the burrow (See Fig. 3). We also measured 169 the entrance diameter (ED) from field photographs.

170 A 3D model of the burrows was generated based on photographs taken with a Lumix DMC171 FZ70 camera and processed in the software Agisoft Photoscan Professional v.1.4.6. The resulting 172 models were export in OBJ files to Adobe Photoshop CC 2017 and converted to U3D files (a 173 standard format for 3D), to compose a PDF file for easier visualization.

174 The casts and spider specimens collected were stored in the "Colección Paleontológica de la 175 Facultad de Ciencias Exactas y Naturales" of the Universidad Nacional de La Pampa (acronym 176 GHUNLPam), and one of the Pavocosa sp. specimens in the Museo Argentino de Ciencias 177 Naturales "Bernardino Rivadavia” (acronym MACN-Ar). The specimens were preserved in 178 EtOH 80\%; photographs of preserved specimens were taken with a Leica DFC 290 digital 179 camera mounted on a Leica M165 C stereoscopic microscope. Images taken in different focal 180 planes were combined with Helicon Focus 4.62 Pro (www.heliconsoft.com). The width between 
181 the fangs of chelicera in collected spider specimens was measured for comparison with the marks 182 preserved in the casts.

\section{RESULTS}

\section{Ocurrence of Pavocosa sp. burrows}

In early spring (October, 2016) abundant burrow entrances of similar size were observed in the sandflat surface. Spider burrows were found in a sparsely vegetated sandflat ( 0 to $10 \%$ of plant coverage), with the only presence of a small halophyte shrub Heterostachys ritteriana Ungernappearing either open and covered with a thin ring of silk (Fig. 4C) or partially closed with a plug of silk and sediment pellets (Fig. 4D). Surrounding the burrow (in a radius of up to $64 \mathrm{~cm}$ ) abundant small spherical sediment pellets were observed (with a density of up to 290 pellets $/ \mathrm{m}^{2}$ ) (Fig. 4F), at this time no casts were made. In late spring (December, 2016) burrow density was lower, they were restricted to a small area on the edge of the saline lake with sparse vegetation at the boundary with the bare sandflat. A total of eight casts were obtained, five were inhabited burrows, while the remaining were abandoned. The inhabited burrows showed up two sacs of eggs in the lowermost part (Fig.4E). During the field trip conducted in summer (February, 2017), very few burrows were observed, all open and partially filled with some sand they seem to be uninhabited for a long time. At this time only one uninhabited burrow was casted.

Sandflat sediments

202 The pit dug in the saline sandflat where the burrows occur was $60 \mathrm{~cm}$ deep (Fig. 5A). The 203 uppermost bed (\# 1) is $13 \mathrm{~cm}$ thick and mainly composed of poorly-sorted pale yellowish brown 
204 (10 YR 6/2) silty sand containing $0.9 \%$ of carbonate (Figs. 5B, 5C). The lower $5 \mathrm{~cm}$ of bed 1

205 exhibits thin diffuse evaporite laminae and a mud lamina. This bed contained the studied

206 Pavocosa sp. burrows. Bed 2 (7 cm thick) is poorly-sorted moderate yellowish brown (10 YR

$2075 / 4)$ silty sand, with massive structure and $0.8 \%$ of carbonate. Bed 3 (5 cm thick) is very poorly-

208 sorted, dark yellowish brown (10 YR 4/2), silty sand with massive structure, containing $1.4 \%$ of

209 carbonate and small (2 mm) gastropod shells comparable with Heleobia Stimpson, 1865. The 27

$210 \mathrm{~cm}$ thick bed 4 is very poorly-sorted, massive, moderate brown (5 YR 4/4), sandy silt containing

$2110.6 \% \mathrm{CO}_{3}$. The $6 \mathrm{~cm}$ thick lowermost bed (\# 5), is mainly composed of fine-grained, pale

212 yellowish brown (10 YR 6/2) sand with abundant carbonate cement that matches with the water

213 table. Field work was conducted in rainy days, however, the water table was well below the

214 bottom of Pavocosa sp. burrows (about 40-45 $\mathrm{cm}$ below the bottom of the burrows).

\section{Producer of the burrows: Pavocosa sp.}

217 Although the genus Pavocosa Roewer, 1960 was never reviewed, and its composition was

218

219

220

221

222

223

224

225

226 recently questioned (Toscano-Gadea \& Costa, 2016), the inclusion of the material studied as an undescribed species of Pavocosa was possible through the comparison of the males and females of Pavocosa gallopavo (Mello-Leitão, 1941) (Fig. 6A, 6C), the type species of the genus. The male holotype of P. gallopavo (MLP-15065) and females from MACN collection were examined and they share with Pavocosa sp. (Fig. 6B, 6D) the presence of deep furrows on the atrium, parallel to the median septum of the female epigyne and the coloration pattern (Fig. 6A, 6B), characters probably diagnostic of the genus (L Piacentini, personal observations). The enlarged posterior eyes in Pavocosa sp. and the shape of the genitalia are clearly distinctive from $P$. gallopavo. The fangs of specimens captured inside the burrows $(n=3)$ are separated about 3.9 - 
$2274.6 \mathrm{~mm}$ (Fig. 7H). The environmental distribution of Pavocosa is little known, although it seems

228 to prefer bare patches in sandy grassland soils (L. Piacentini, personal observations).

229 Additional material of the described species from Córdoba (Salinas Grandes, 2950’39” S,

230 6440'16” W), Santiago del Estero and San Luis (Pampa de las Salinas; 32¹2’19” S, 64³9’13”

231 W) were recorded from MACN-Ar collection (23503, 23505 to 23513, 24096, and 38710), all

232 from saline environments. The burrows of Pavocosa sp. from Córdoba (A. Peretti, C. Mattoni

233 and M. Izquierdo, personal communication, 2008) and San Luis (M. Ramírez pers

234 communication, 2016) are very similar to those described in this work.

235

236

237

238

239

240

241

242

243

244

245

246

247

248

249

\section{Pavocosa sp. burrows}

The inhabited burrows (n=5) (Fig. 7A-E) are simple, vertical and circular shafts with an inclination of the main axis of $72^{\circ}-88^{\circ}$ (average: $80^{\circ}$ ), the length ranges from 115 to $130 \mathrm{~mm}$ (average: $120 \mathrm{~mm}$ ). The diameter gradually increases from an upper narrow neck that is 12 to 15 $\mathrm{mm}$ wide (average $14 \mathrm{~mm}$ ) and 5-8 $\mathrm{mm}$ long (average $6 \mathrm{~mm}$ ), to a maximum diameter in the lower half ranging from 18 to $28 \mathrm{~mm}$ (average $23 \mathrm{~mm}$ ). The outline of the entrance and crosssection of the maximum diameter of the burrows are subcircular. In average, the widest part of the burrow is $64 \%$ larger than the neck. The burrow cast surface of five burrow casts exhibits sparse ornamentation in the form sets of two linear parallel ridges (Fig. 7F-G) about 2.8-4.4 mm long (average $3.4 \mathrm{~mm}, \mathrm{n}=16$ ) and 2.2-4.5 mm wide (average: $3.4 \mathrm{~mm}, \mathrm{n}=14$ ) aligned oblique to perpendicular (range: $42^{\circ}-89^{\circ}$, average: $64^{\circ}, \mathrm{n}=14$ ) to the main axis of the burrow. The supplementary material contains interactive PDF files of each Pavocosa sp. burrow casts.

\section{Modified Pavocosa sp. burrows}


250 Uninhabited Pavocosa sp. burrows (n=4) (Fig. 8) display some kind of modification in its overall

251 form (Fig. 6A-D) (see Supplemental Material for interactive 3D models of each cast). All are

252 composed of a highly inclined shaft (range: $78^{\circ}-87^{\circ}$; average: $84.5^{\circ}$ ), with an upper constriction

253 and an average maximum diameter ranging from 15 to $22 \mathrm{~mm}$ (average $19 \mathrm{~mm}$ ). Three types of

254 modifications were identified. 1) Subcylindrical burrows (108-116 mm long by 15-22 mm wide)

255 with a subhorizontal expansion in the middle part forming an "umbrella" (Figs. 8A-B). The shaft

256 boundary exhibit scarce ornamentation in the form of sets of two linear parallel ridges similar to

257 those of the inhabited Pavocosa sp. burrows. The "umbrella" structure shows an oval to lobed

258 shape in the plan view (Figs. 8C-D), with minimum diameter of 47-54 mm and a maximum

259 diameter of 59-66 mm. The "umbrella" surface exhibits an ornamentation in form of small (1.4

$260 \mathrm{~mm}$ in diameter) rounded knobs (Fig. 8E). The burrow bottom is rounded or partially filled with

261 sediments. 2) Subcylindrical burrow about $116 \mathrm{~mm}$ long and $21 \mathrm{~mm}$ wide with two smaller

262 burrows ( $8 \mathrm{~mm}$ of diameter) arising at the bottom of the larger burrow (Fig. $8 \mathrm{~F}$ ). 3) A third form

263 is a $143 \mathrm{~mm}$ high and $101 \mathrm{~mm}$ wide funnel that ends in a $24 \mathrm{~mm}$ wide cylindrical shaft with an

264 oblique bottom (Fig. $8 \mathrm{G}$ ). The surface of the funnel exhibits sets of two parallel ridges (about 21

$265 \mathrm{~mm}$ long and $9.2 \mathrm{~mm}$ wide) running oblique to the major axis (Fig. 8H).

266

267 DISCUSSION

268 Clues for identification of wolf-spider burrows in the fossil record

269 Pavocosa sp. produces open burrows with distinctive features as cylindrical, nearly vertical, silk

270 lined shaft showing a gradual downward widening, a neck in the top and a rounded end, the

271 entrance sometimes plugged with a cap of silk and sediment pellets, and a particularly distinctive

272 surface ornamentation on the burrow margin. Most of these features are shared with other wolf

273 spider burrows documented in the literature (Fig. 1) (Hancock, 1899; Ratcliffe \& Fagerstrom, 
274 1980; Carrel, 2008; Suter, Stratton \& Miller, 2011; Albín, Simó \& Aisenberg, 2015; Hils \&

275 Hembree, 2015; Vrenozi \& Uchman, 2015; Foelix et al., 2017; Uchman, Vrenozi \& Muceku,

276 2017). In particular, the presence of a neck and downward widening seem to be a common

277 feature in wolf spider burrows found in natural settings. For Pavocosa sp. burrows this widening

278 is about $64 \%$, whereas it is $52 \%$ for Trochosa hispanica (Uchman, Vrenozi \& Muceku, 2017).

279 Another highly distinctive feature of Pavocosa sp. burrows is its surface ornamentation in the

280 form of two short parallel ridges oblique to perpendicular with the burrow axis that appear in the

281 most burrow casts (Fig. 7F-G). Although this surface ornamentation was not recorded in some

282 casts, probably due to the presence of the silk lining, all the burrow casts with delicate

283 preservation of the surface texture exhibit these paired ridges. This feature was not identified in

284 previous studies of wolf spider burrows and is potentially related to the burrowing technique

285 used by Pavocosa sp. Spiders uses two main mechanisms of excavation: 1) by pushing and

286 compressing sediment using the pedipalps (Hils \& Hembree, 2015) and 2) by scraping the soil

287 with help of fangs from chelicerae (Stokes, 1884; Suter, Stratton \& Miller, 2011; Hils \&

288 Hembree, 2015; Foelix et al., 2016). Although we have not observed Pavocosa sp. during

289 digging, the sets of two linear parallel ridges observed on the better preserved burrow casts

290 surface are similar in form and shape with the arrangement of fangs of collected specimens. The

291 distance between fangs (3.9-4.6 mm) overlaps with distance between ridges within a set (2.2-4.5

$292 \mathrm{~mm}$ ). Thus we propose that excavation in Pavocosa sp. involves the use of fangs, as in type 2

293 excavation mechanism mentioned above.

294 Silk lined burrows are unique in spiders and essentially impart stability in soft substrates to

295 prevent collapse (Ratcliffe \& Fagerstrom, 1980; Foelix et al. 2017; Hils \& Hembree, 2015). The

296 presence of organic matter in the form of a silk lining increase the potential of preservation of 
297 wolf spider burrows (Uchman, Vrenozi \& Muceku, 2017), well above those of all others

298 arthropods that habit in the same environment.

299 Spider burrows may result modified by reoccupation or predation, as well as by environmental

300 changes. Reoccupation of abandoned lycosid and mygalomorph burrows by lizards, centipedes,

301 moths, wasps, beetles and ants have been documented (e.g., Fellows, Fenner \& Bullet, 2009).

302 Ants have been also observed invading occupied wolf spider burrows with the purpose of prey

303 piracy (Marshall, 1995). However, it has not been documented if the reoccupation results in any

304 change in the morphology of the burrow. Common spider burrow disturbances caused by

305 predation includes those produced by pompilid wasps that preys the spider and occasionally digs

306 a tunnel perpendicular to the spider burrow (Gwynne, 1979; Costa et al., 2004), and excavation

307 of the upper part of the burrows by armadillos (Suter, Stratton \& Miller, 2011).

308 Most of Pavocosa sp. burrows are susceptible to go through a large amount of disturbances,

309 including those caused by the reoccupation by another organism (Fig. 8A-B and F) and predation

310 of the dweller (Fig. 8G). Two kinds of burrow modifications observed during this study are

311 tentatively related to reoccupation of burrows: those with an expansion in the middle part as a

312 kind of "umbrella" (Fig. 8A-B) and that with smaller excavations at the bottom of the burrow

313 (Fig. 8F). Even if we cannot discard an inorganic origin (i.e., evaporite leaching) for the

314 "umbrella" structure seen in some casts is highly reminiscent of oval to lobed ant nest chambers

315 (Tschinkel, 2003). Although no ants were recorded when making the casts, they were commonly

316 seen in the sandflat surface constructing nests within vertebrate footprints and abandoned

317 burrows, presumably to avoid the hard efflorescent salt crust of the sandflat surface. The

318 producer of the smaller burrows at the bottom of Pavocosa sp. burrow is unknown. Funnel

319 shaped burrows (Fig. 8G) are alike to the probing marks related to predation by small mammals, 
320 similar structures are described in the literature including Sarzetti \& Genise (2011) from northern

321 Argentina, Suter, Stratton \& Miller (2011: fig. 2), and Platt (2014), the two latter from

322 Mississippi, USA. Small mammals found in this area with similar behaviours are the armadillos

323 and skunks. The more likely producer is a small armadillo as suggested by the size of the funnel

324 and most importantly by the presence of sets of two large ridges in the cast surface (compare

325 Platt, 2014), interpreted as scratch marks (Fig. 8H).

326 Preservation of burrows in the margin of saline lakes, including those of wolf spiders, are

327 affected by environmental factors like early cementation by evaporites and swelling of expansive

328 clays during flooding (e.g., Scott, Renaut \& Owen, 2010). Cementation by evaporites favors

329 preservation, whereas wetting and drying cycles of swelling clays can destroy the burrows.

330 Both the original Pavocosa sp. burrows and those modified by reoccupation or predation can be

331 compared with known ichnogenera. The simple vertical forms are grossly comparable with

332 Skolithos (see Alpert, 1974 and Schlirf, 2000); some significant differences are the presence of a

333 constriction or neck, the downward widening and the surface texture. These features are

334 potentially significant ichnotaxonomicaly (Schlirf \& Uchman, 2005), although no proposed

335 ichnotaxon match them. Slight variations in burrow diameter are allowed in Skolithos (Alpert,

336 1974; Schlirf, 2000), although the observed differences in Pavocosa sp. burrow diameter are

337 significant and repetitive. There are a few examples of ornamented Skolithos, all of them from

338 continental settings and tentatively assigned to insects or spiders, but they are not comparable to

339 that observed in Pavocosa sp. burrows (Bromley \& Asgaard, 1979; Schlirf et al. 2001; Netto,

340 2007). These ornamented Skolithos exhibit indistinct striations, except for the example described

341 by Netto (2007) that display horizontal striae forming a circular ring. In consequence, there is no

342 known fossil burrow with all the features described for the studied wolf spider burrows. 
343 Modified Pavocosa sp. burrows with an "umbrella" if fossilized can be confused with

344 Daimoniobarax Smith et al., 2011; in particular, the umbrella is comparable with chambers and

345 the vertical burrow of the spider is comparable with the shaft connecting the chambers in

346 Daimoniobarax. A potential difference is the considerably larger diameter of the burrow

347 connecting the chambers that averages $40 \%$ of chamber diameter in the modified Pavocosa sp.

348 burrow and 10\% in Daimoniobarax (Smith et al., 2011). The modified Pavocosa sp. burrow with

349 smaller burrows arising from the bottom can be confused with a downward bifurcation as seen in

350 rhizoliths (Klappa, 1980), a roughly similar rhizolith was figured by Melchor et al. (2002, fig.

351 3B). Finally, funnel shaped burrows can be compared with several ichnogenera including

352 Monocraterion Torell, 1870; Conostichnus Lesquereux, 1876; Rosselia Dahmer, 1937;

353 Conichnus Männil, 1966; and Cornulatichnus Carroll \& Trewin, 1995 (see also Platt, 2014). A

354 fundamental difference with these ichnogenera is the lack of large paired surface ridges, as seen

355 in the predated Pavocosa sp. burrow. Further differences are: 1) Monocraterion shows smaller

356 radial burrows arising from the central funnel (Jensen, 1997); 2) Conostichnus exhibits a

357 duodecimal symmetry and transverse and longitudinal ridges and furrows (Pemberton et al.

358 1988); 3) Rosselia is a bulbous structure with a concentrically laminated fill (Schlirf et al. 2002);

359 4) Conichnus exhibits a rounded apex and common chevron-like fill (Pemberton et al. 1988); and

360 5) Cornulatichnus has a well-developed lining (Carroll \& Trewin, 1995). Conical sedimentary

361 structures of inorganic origin can also resemble Pavocosa sp. burrows modified by predation.

362 Buck \& Goldring (2003) identified two main inorganic processes that produced conical

363 sedimentary structures: collapse and dewatering. The former is distinguished by V or U shaped

364 downwarping of lamination and the latter by deformed lamination and massive zone at the base 
365 of the cone (Buck \& Goldring, 2003). These features allow distinction from the predated (i.e.,

366 funnel-shaped) Pavocosa sp. burrow, that would have a massive fill.

367 Burrowing spiders belong to Mesothelae and Opisthothelae (Coddington, 2005). Although

368 Mesothelae dates back to the Late Carboniferous, the only known burrowing group (Liphistiidae)

369 has no fossil record (Dunlop, Penney \& Jekel, 2017). Within Opisthothelae, burrowing spiders

370 are found in the Middle Triassic to Recent Mygalomorphae, which includes the tarantulas and

371 trapdoor spiders and in the Cretaceous to Recent Lycosoidea (included in Araneomorphae) that

372 comprises the wolf spiders (Dunlop, 2010; Dunlop, Penney \& Jekel, 2017). The oldest putative

373 example of Lycosoidea comes from Turonian beds of Botswana (Selden, Anderson \& Anderson,

374 2009); which is close to the age of the superfamily suggested by phylogenetic studies (70 Ma,

375 after Garrison et al., 2016); although most fossil records are from the Paleogene to Recent

376 (Dunlop, Penney \& Jekel, 2017). In addition, phylogenetic studies on web type suggest that the

377 spider common ancestor likely foraged from a subterranean burrow, mostly sealed by a trapdoor

378 (Garrison et al. 2016). In consequence, the record of spider burrows can be traced back, at least

379 to the Middle Triassic (and probably to the Late Carboniferous) and lycosid burrows in Late

380 Cretaceous or Cenozoic rocks.

381 The use of fossil to calibrate molecular phylogenies is an uprising topic in spider biology (Planas

382 et al, 2013; Wood et al, 2013; Moradmand et al, 2014). The absence of reliable fossil record,

383 such as in Lycosidae (Penney, 2001), is an important impediment and the potential identification

384 of wolf spider burrows on the fossil record, with the clues provided herein, can be a useful

385 alternative source of data.

387 Environmental distribution of Pavocosa sp. burrows

388 The sediments of the sandflat containing the Pavocosa sp. burrows reflect the interaction 
389 between the nearby eolian and lacustrine settings. The two upper beds are essentially sandy

390 deposits with a mixture of dominant fine sand and silt (samples S1 and S2; Fig. 5). The

391 dominance of the coarse fraction (fine sand), poor sorting and the frequency distribution is

392 comparable with those of modern interdune deposits (e.g., Ahlbrandt, 1979). Poorly defined

393 laminae with evaporites in bed 1 are interpreted as result of capillary rise and precipitation from

394 brines. The sandy nature of the material where Pavocosa sp. excavated the burrows and their

395 location $40 \mathrm{~cm}$ above the water table suggests preference for well-drained substrates. In contrast,

396 the lowermost silty beds (samples S3 and S4; Fig. 5) are interpreted as dominantly lacustrine

397 deposits, on the basis of the fine grain size and the presence of gastropods shells. Heleobia is a

398 very common extant gastropod in South America recorded in estuarine and continental settings,

399 including saline lakes (see review in Cazzaniga, 2011). In consequence, the logged section

400 reflects the migration of the parabolic dune towards the northeast over the Gran Salitral

401 lacustrine sediments (for a more detailed interpretation of dune deposits see Melchor et al.,

402 2012). The presence of abundant Pavocosa sp. burrows in the well-drained sandflat deposits of

403 the Gran Salitral and similar occurrences of reported in the literature (e.g., Hudson \& Adams,

404 1996) suggest that wolf spider colonization of saline lakes occur preferentially during dry

405 periods of the lake.

406 Wolf spiders (Lycosidae) are one of the most successful spider families distributed in most of the

407 habitats around the World (World Spider Catalog, 2017). Lycosids display a wide range of prey-

408 capture strategies from web builders to burrow-dwellers or vagrant species. The use of burrows

409 in wolf spiders can be in some cases obligatory, temporary in male juveniles, and as brood care

410 in females (Logunov, 2011), or merely facultative in absence of objects as a rock that serves as a

411 retreat. In general, burrows in wolf spiders are related to open areas of xerothermic habitats with 
412 sparse or no vegetation (e.g. sandy seashores, dune heaths, limestone areas and desert

413 nanophanerophyte steppe) (Logunov, 2011). Some wolf spider species have specific habit

414 preferences, as is the case of halotolerant species that inhabit the surface of salt lakes, most of

415 them included in Tetralycosa and other species as Lycosa salifodina McKay, 1976 from

416 Australia (Hudson \& Adams, 1996; Framenau \& Leung, 2013), and two other Argentinian

417 species including Pavocosa sp. In particular, Pavocosa sp. has been documented in saline lakes

418 of Cordoba, Santiago del Estero, San Luis and La Pampa. In consequence, it is likely that the

419 described burrows are typical of saline environments.

\section{CONCLUSIONS}

422 Observations on the burrows of the wolf spider Pavocosa sp. in the coast of a saline lake in 423 central Argentina suggest that:

424 1) Pavocosa sp. produces burrows with recognizable features as open, cylindrical, nearly

425 vertical, silk lined shafts, showing a gradual downward widening, with a neck and the entrance

426 and a rounded end, and a particularly distinctive surface ornamentation on the burrow margin.

427 These features are considered typical of wolf spider burrows.

428 2) Burrows are susceptible to go through a large amount of disturbances, including reoccupation

429 by another organism or by predation of the dweller. Two types of modified Pavocosa sp. are

430 related to reoccupation of burrows: those with a lateral expansion in the middle part as a kind of

431 "umbrella" and another with smaller excavations at the bottom of the burrow. Predation by small

432 mammals results in funnel-shaped burrows.

433 3) Pavocosa sp. burrows have significant differences with those found in the Skolithos 
434 ichnospecies. Such features as the presence of a neck, a downward widening and the surface

435 texture make them identifiable in the fossil record. The modified Pavocosa sp. burrows can be 436 confused with Daimoniobarax, rhizoliths, and several conical sedimentary structures, although

437 some key aspects allow their distinction.

438 4) The features of Pavocosa sp. burrows that are considered diagnostic of wolf spider burrows 439 are not identified to date in any published description of fossil examples.

440 5) Pavocosa sp. colonized well drained sandy substrates of eolian origin on the margin of a 441 saline lake. Known occurrences of this species suggest that it is a halotolerant wolf spider that 442 inhabits the surface of saline lakes. Furthermore, as the wolf spiders avoid flooded substrates, it 443 is suggested that the occurrence of wolf spider burrows in saline lakes is probably related to dry 444 periods.

6) The potential record of wolf spider burrows dates back to the Paleogene (possibly Late Cretaceous). The presence of silk lining increases its potential of preservation and the typical morphology and the surface texture render them recognizable in the fossil record.

Acknowledgements. Silverio Feola, Mauricio Fernández, Sofía Mulatero, Luis Torres and 450 Angélica Tamame helped during field work. The landowner of Puesto La Porfía, Mr Tránsito 451 Cerda is thanked for permission to work on his property.

452

453

454

\section{BIBLIOGRAPHY}


457 Ahlbrandt TS. 1979. Textural parameters of eolian sands. In: Mckee, E.D., A study of global 458 sand seas. Geological Survey Professional Paper, 1052:21-52.

459 Aisenberg A, Viera C, Costa FG. 2007. Daring females, devoted males, and reversed sexual size 460 dimorphism in the sand-dwelling spider Allocosa brasiliensis (Araneae, Lycosidae). Behavioral 461 Ecology and Sociobiology, 62:29-35. DOI 10.1007/s00265-007-0435-x.

462 Albín A, Simó M, Aisenberg A. 2015. Characterisation of burrow architecture under natural 463 conditions in the sand-dwelling wolf spider Allocosa brasiliensis. Journal of Natural History, 464 50:201-209. DOI 10.1080/00222933.2015.1068395.

465 Alpert SP. 1974. Systematic Review of the Genus Skolithos. Journal of Paleontology, 48(4):661466 669. Available at http://www.jstor.org/stable/1303217.

467 Banks N. 1895. Some Missouri spiders. Entomological News, 6:204-207.

468 Bromley RG. 1981. Concepts in ichnology illustrated by small round holes in shells. Acta 469 Geológica Hispánica, 16:55-64.

470 Bromley RG, Asgaard U. 1979. Triassic freshwater ichnocoenoses from Carlsberg Fjord. 471 Palaeogeography, Palaeoclimatology, Palaeoecology, 28:39-80.

472 Bryson HR. 1939. Identification of soil insects by their burrow characteristics. Transactions of 473 the Kansas Academy of Science. 42:245-253.

474 Buck SG, Goldring R. 2003. Conical sedimentary structures, trace fossils or not? Observations, 475 experiments, and review. Journal of Sedimentary Research, 73:338-353.

476 Carrel JE. 2008. Differential survival of Geolycosa xera archboldi and G. hubbelli (Araneae, 
477 Lycosidae) after fire in Florida scrub. Journal of Arachnology, 36:595-599.

478 Carroll S, Trewin NH. 1995. Cornulatichnus: a new trace fossil from the Old Red Sandstone of 479 Orkney. Scottish Journal of Geology, 31:37-41.

480 Cazzaniga N. 2011. El género Heleobia (Caenogastropoda: Cochliopidae) en América del Sur. 481 Amici Molluscarum, special number: 1-79.

482 Chikhale MP, Santape GB, Bodkhe AK. 2013. Some observations on burrow architecture of 483 burrowing spider Geolycosa Montgomery, 1904 (Araneae, Lycosidae) At Vairat, Melghat Tiger 484 Reserve, Maharashtra, India. Indian Journal of Arachnology, 2:34-38.

485 Cloudsley-Thompson JL. 1983. Desert adaptation in spiders. Journal of Arid Environments, $486 \quad 4: 307-317$.

Coddington JA. 2005. Phylogeny and classification of spiders. In: Ubick D, Paquin P, Cushing

PE, Roth V. (Eds.), Spiders of North America: an Identification Manual. American Arachnological Society, 18-24.

Costa FG, Pérez-Miles F, Mignone A. 2004. Pompilid wasp interactions with burrowing 491 tarantulas: Pepsis cupripennis versus Eupalaestrus weijenberghi and Acanthoscurria suina (Araneae, Theraphosidae). Studies on Neotropical Fauna and Environment, 39(1):37-43. DOI $10.1080 / 01650520412331270945$. 
497 of Economic Paleontologists and Mineralologists, Special Publication 71:47-55.

498 Dahmer G. 1937. Lebensspuren aus dem Taunusquarzit und den Siegener Schichten

499 (Unterdevon). Preussischen Geologischen Landesanstalt zu Berlin Jahrbuch 1936, 57:523-539.

500 De Simone GA, Aisenberg A, Peretti AV. 2015. Female and juvenile burrow digging in Allocosa 501 brasiliensis, a South American sand-dwelling wolf spider. Arachnology, 16(8):276-280.

502 http://dx.doi.org/10.13156/arac.2015.16.8.276.

503 Dunlop JA. 2010. Geological history and phylogeny of Chelicerata. Arthropod Structure and 504 Development, 39:124-142. DOI 10.1016/j.asd.2010.01.003.

505 Dunlop JA, Braddy SJ. 2011. Cteniza bavincourti and the nomenclature of arachnid-related trace 506 fossils. The Journal of Arachnology, 39:250-257.

507 Dunlop JA, Penney D, Jekel D. 2017. A summary list of fossil spiders and their relatives. In 508 World Spider Catalog. Natural History Museum Bern, Available at http://wsc.nmbe.ch, version 50918.5 (accessed 11 September 2017).

510 Fellows HL, Fenner AL, Bull CM. 2009. Spiders provide important resources for an endangered 511 lizard. Journal of Zoology, 279(2):156-163. DOI 10.1111/j.1469-7998.2009.00600.x.

512 Fernandes ACS, Borghi L, Carvalho IS. 1992. Icnofósseis de Artropodes na Formação Resende

513 (Bacia de Resende, RJ). Academia Brasileira de Ciências, 64:269-275.

514 Foelix R, Rechenberg I, Erb B, Joel AC. 2016. Über den Bau der Wohnröhren bei 515 wüstenlebenden Spinnen. Arachne, 21:4-17.

516 Foelix R, Rechenberg I, Erb B, Albín A, Aisenberg A. 2017. Sand transport and burrow 
517 construction in sparassid and lycosid spiders. Journal of Arachnology, 45:255-264.

518 Framenau VW, Leung AE. 2013. Costacosa, a new genus of wolf spider (Araneae, Lycosidae)

519 from coastal north-west Western Australia. Records of the Western Australian Museum, 83:173-

520 184. DOI 10.18195/issn.0313-122x.83.2013.173-184.

521 Framenau VW, Hudson P. 2017. Taxonomy, systematics and biology of the Australian

522 halotolerant wolf spider genus Tetralycosa (Araneae: Lycosidae: Artoriinae). European Journal

523 of Taxonomy, 335:1-72. https://doi.org/10.5852/ejt.2017.335.

524 Fürsich FT. 1981. Invertebrate trace fossils from the upper Jurassic of Portugal. Comunicacoes

525 Servicos Geologicos de Portugal, 67:153-168.

526 Garrison NL, Rodriguez J, Agnarsson I, Coddington JA, Griswold CE, Hamilton CA, Hedin M,

527 Kocot KM, Ledford JM, Bond JE. 2016. Spider phylogenomics: untangling the Spider Tree of

528 Life. PeerJ, 4:e1719. DOI 10.7717/peerj.1719.

529 Gwynne DT. 1979. Nesting biology of the spider wasps (Hymenoptera: Pompilidae) which prey

530 on burrowing wolf spiders (Araneae: Lycosidae, Geolycosa). Journal of Natural History, $531 \quad 13: 681-692$.

532 Haldeman SS. 1840. Supplement to number one of 'A monograph of the Limniades, and other

533 freshwater bivalve shells of the apparently new animals in different classes, and names and

534 characters of the subgenera in Paludina and Anculosa'. J. Dobson, Philadelphia. 3 pp.

535 Hancock JL. 1899. The castle-building spider. Entomological News, 10:23-29.

536 Hasiotis ST. 2002. Continental Trace Fossils. Short Course Notes, SEPM (Society for 
537 Sedimentary Geology), Tulsa, 134 p.

538 Hasiotis ST. 2007. Continental ichnology: fundamental processes and controls on trace fossil

539 distribution. The continental realm. In: Miller W III (ed) Trace Fossils: Concepts, Problems,

540 Prospects. Elsevier Sci, Amsterdam, 268-284.

541 Hasiotis ST, Bourke MC. 2006. Continental trace fossils and museum exhibits: displaying

542 burrows as organism behaviour frozen in time. The Geological Curator, 8(5):211-226.

543 Hembree DI. 2017. Neoichnology of tarantulas (Araneae: Theraphosidae): Criteria for

544 recognizing spider burrows in the fossil record. Palaeontologia Electronica, 20.3.45A:1-30.

545 Available at palaeo-electronica.org/content/2017/2003-neoichnology-of-tarantulas.

546 Hentz NM. 1844. Descriptions and figures of the araneides of the United States. Boston Journal 547 of Natural History, 4:386-396.

548 Hickman VV.1944. Scorpions and spiders. In: The Simpson desert expedition, 1939-Scientific

549 reports No. 1, Biology. Transactions of the Royal Society of South Australia, 68:18-48.

550 Hils JM, Hembree DI. 2015. Neoichnology of the burrowing spiders Gorgyrella inermis

551 (Mygalomorphae: Idiopidae) and Hogna lenta (Araneomorphae: Lycosidae). Palaeontologia

552 Electronica, 18.1.7A:1-62. Available at palaeo-electronica.org/content/2015/1057-neoichnology-

553 of-spiders.

554 Hudson P, and Adams M. 1996. Allozyme characterisation of the salt lake spiders (Lycosa:

555 Lycosidae: Araneae) of southern Australia: Systematic and population genetic Implications.

556 Australian Journal of Zoology 44:535-567. https://doi.org/10.1071/ZO9960535 
557 INTA, UNLPam. 1980. Inventario Integrado de los Recursos Naturales de la Provincia de la

558 Pampa. Buenos Aires. ISAG.

559 Jensen S. 1997. Trace fossils from the Lower Cambrian Mickwitzia sandstone, south-central

560 Sweden. Fossils and Strata, 42:111.

561 Klappa CF. 1980. Rhizoliths in terrestrial carbonates: classification, recognition, genesis and

562 significance. Sedimentology, 27:613-629.

563 Koch CL. 1838. Die Arachniden. Nürnberg, Vierter Band, 109-144, Funfter Band, 1-124.

564 Lesquereux L. 1876. Species of fossil marine plants from the Carboniferous Measures.

565 Geological Survey of Indiana, Annual Report, 7:134-145.

566 Linck O. 1949. Lebens-Spuren aus dem Schilfsandstein (Mittl. Keuper, km 2) NW-

567 Württembergs und ihre Bedeutung für die Bildungsgeschichte der Stufe. Jahreshefte des Vereins

568 für vaterländische Naturkunde in Württemberg 97-101:1-100.

569 Logunov DV. 2011. Sexual size dimorphism in burrowing wolf spiders (Araneae: Lycosidae).

570 Proceedings of the Zoological Institute RAS, 315:274-288.

571 Macsotay O. 1967. Huellas problemáticas y su valor paleoecológico en Venezuela. GEOS

572 Revista Venezolana de Ciencias de la Tierra, 16:1-87.

573 Männil R. 1966. O vertikalnykh norkakh zaryvaniya v ordovikskikh izvestnyakakh Pribaltiki. In

574 Hecker RF. (ed.), Organizm i sreda v geologischeskom proshlom. Akademiya Nauk SSSR.

575 Paleontologicheskij Institut, 200-207.

576 Marshall SD. 1995. Natural history, activity patterns, and relocation rates of a burrowing wolf 
577 spider: Geolycosa xera archboldi (Araneae, Lycosidae). Journal of Arachnology, 23:65-70.

578 Marshall SD. 1996. Evidence for territorial behavior in a burrowing wolf spider. Ethology, $579 \quad 102: 32-39$.

580 McCrone JD. 1963. Taxonomic status and evolutionary history of the Geolycosa pikei complex 581 in the Southeastern United States (Araneae, Lycosidae). American Midland Naturalist, 70:47-73.

582 McKay RJ. 1976. The wolf spiders of Australia (Araneae: Lycosidae): 8. Two new species 583 inhabiting salt lakes of Western Australia. Memoirs of the Queensland Museum, 17: 417-423.

584 Melchor RN, Casadío S. 2000. Descripción Geológica de la Hoja 3766-III “La Reforma” 585 (1:250.000), Provincia de la Pampa. Boletín del Servicio Geológico Minero Argentino, 295: 158670.

587 Melchor RN, Genise JF, Miquel SE. 2002. Ichnology, sedimentology and paleontology of 588 Eocene calcareous paleosols from a palustrine sequence, Argentina. Palaios, 17:16-35.

589 Melchor RN, Genise JF, Umazano AM, Superina M, 2012. Pink fairy armadillo meniscate 590 burrows and ichnofabrics from Miocene and Holocene interdune deposits of Argentina: 591 palaeoenvironmental and palaeoecological significance. Palaeogeography, Palaeoclimatology, 592 Palaeoecology, 350-352:149-170.

593 Mello-Leitão CF de. 1941. Las arañas de la provincia de Santa Fe colectadas por el Profesor 594 Birabén. Revista del Museo de La Plata (N.S. Zoología), 2:199-225.

595 Mello-Leitão CF de. 1945. Arañas de Misiones, Corrientes y Entre Ríos. Revista del Museo de 596 La Plata (N.S. Zoología), 4:213-302. 
597 Mikuś P, Uchman A. 2012. Beetle burrows with a terminal chamber: a contribution to the

598 knowledge of the trace fossil Macanopsis in continental sediments. Palaios, 28:403-413.

599 Murphy NP, Framenau VW, Donnellan SC, Harvey MS, Park YC, Austin AD. 2006.

600 Phylogenetic reconstruction of the wolf spiders (Araneae: Lycosidae) using sequences from the 601 12S rRNA, 28S rRNA, and NADH1 genes: Implications for classification, biogeography, and the 602 evolution of web building behavior. Molecular Phylogenetics and Evolution, 38:583-602.

603 Moradmand M, Schönhofer A, Jäger P. 2014. Molecular phylogeny of the spider family

604 Sparassidae with focus on the genus Eusparassus and notes on the RTA-clade and

605 'Laterigradae'. Molecular Phylogenetics and Evolution, 74:48-65.

606 Netto RG. 2007. Skolithos-dominated piperock in non-marine environments: an example from 607 the Triassic Caturrita Formation, southern Brazil. In: Bromley RG, Buatois LA, Mángano MG, 608 Genise JF, Melchor RN (eds.), Sediment- Organism Interactions: a Multifaceted Ichnology. 609 SEPM, Special Publication, 88:109-121.

610 Pemberton SG, Frey RW, Bromley RG. 1988. The ichnotaxonomy of Conostichus and other 611 plug-shaped ichnofossils. Canadian Journal of Earth Sciences, 25:886 - 892.

612 Penney D. 2001. Advances in the taxonomy of spiders in Miocene amber from the Dominican 613 Republic (Arthropoda: Araneae). Palaeontology. 44:987-1009.

614 Petrunkevitch A. 1910. Some new or little known American Spiders. Annals of the New York 615 Academy of Science, 19:205-224.

616 Planas E, Fernández-Montraveta C, Ribera C. 2013. Molecular systematics of the wolf spider 
617 genus Lycosa (Araneae: Lycosidae) in the Western Mediterranean Basin. Molecular

618 Phylogenetics and Evolution, 67:414-428.

619 Platt BF. 2014. The foraging pits of the nine-banded armadillo, Dasypus novemcinctus

620 (Mammalia: Xenarthra: Dasypodidae), and implications for interpreting conical trace fossils.

621 Palaeontologia Electronica, 17.3.46A:1-17. Available at palaeo-

622 electronica.org/content/2014/1013-armadillo-foraging-pits.

623 Policía de la Provincia de la Pampa. Registros Pluviales para el Departamento Puelén

624 (http://www.policia.lapampa.gov.ar/contenidos/ver/lluvias).

625 Punzo F. (2000). Desert Arthropods: Life History Variations. Berlin, Springer - Verlag, 230 p.

626 Ratcliffe BC, Fagerstrom JA. 1980. Invertebrate lebensspuren of Holocene floodplains: Their

627 morphology, origin and paleoecological significance. Journal of Paleontology, 54:614-630.

628 Roewer CF. 1960. Araneae Lycosaeformia II (Lycosidae) (Fortsetzung und Schluss).

629 Exploration du Parc National de l'Upemba, Mission G. F. de Witte, 55:519-1040.

630 Sarzetti LC, Genise JF. 2011. Predation of soil-nesting Centris muralis (Insecta: Apidae) by

631 armadillos (Zaedyus pichiy) (Mammalia: Cingulata) in La Rioja Province, Northwestern

632 Argentina. Journal of the Kansas Entomological Society.84:179-183.

633 Schlirf M. 2000. Upper Jurassic trace fossils from the Boulonnais (northern France). Geologica 634 et Palaeontologica, 34:145-213.

635 Schlirf M, Uchman A, Kümmel M. 2001. Upper Triassic (Keuper) non-marine trace fossils from

636 the Haßberge area (Franconia, south-eastern Germany). Palāontologische Zeitschrift, 75:71-96. 
637 Schlirf M, Nara M, Uchman A. 2002. Invertebraten-Spurenfossilien aus dem aunusquarzit 638 (Siegen, Unterdevon) von der 'Rossel' nahe Rudesheim. Jahrbucher des Nassauischen Vereins 639 für Naturkunde, 123:43-63.

640 Schlirf M, Uchman A, 2005. Revision of the ichnogenus Sabellarifex Richter, 1921 and its 641 relationship to Skolithos Haldeman, 1840 and Polykladichnus Fürsich, 1981. Journal of 642 Systematic Palaeontology, 3:115-131.

643 Scott JJ, Renaut RW, and Owen RB. 2010. Taphonomic controls on animal tracks at saline, 644 alkaline lake Bogoria, Kenya rift valley: Impact of salt efflorescence and clay mineralogy. 645 Journal of Sedimentary Research 80:639-665.

646 Selden PA, Anderson HM, Anderson JM. 2009. A review of the fossil record of spiders 647 (Araneae) with special reference to Africa, and description of a new specimen from the Triassic 648 Molteno Formation of South Africa. African Invertebrates, 50:105-116.

649 Servicio Meteorológico Nacional. Meteorological station Neuquén Aero, Period 2016- 2017

650 (http://www.smn.gov.ar/).

651 Shepard FP. 1954. Nomenclature based on sand-silt-clay ratios. Journal of Sedimentary 652 Research, 24:151-158.

653 Simon E.1870. Aranéides noveaux ou peu connus du midi de l'Europe. Mémoires de la Société 654 Royale des Sciences de Liège, 2(3):271-358.

655 Smith JJ, Hasiotis ST, Kraus MJ, Woody DT. 2008. Relationship of floodplain ichnocoenoses to 656 paleopedology, paleohydrology, and paleoclimate in the Willwood Formation, Wyoming, during 
657 the Paleocene-Eocene Thermal Maximum. Palaios, 23:683-699.

658 Smith JJ, Platt BF, Ludvigson GA, Thomasson JR. 2011. Ant-nest ichnofossils in honeycomb

659 calcretes, Neogene Ogallala formation, high Plains region of western Kansas, U.S.A.

660 Palaeogeography, Palaeoecology, Palaeoclimatology, 308:383-394.

661 Stimpson W. 1865. Researches upon the Hydrobiinae and allied forms; chiefly made upon

662 materials in the Museum of the Smithsonian Institution. Smithsonian Miscellaneous Collections, 663 201:1-59.

664 Stokes AC. 1884. A burrowing spider. Science, 4:114-116.

665 Suter RB, Stratton GE, Miller PR. 2011. Mechanics and energetics of excavation by burrowing 666 wolf spiders, Geolycosa spp. Journal of Insect Science, 11:22.

667 Torell O. 1870. Petrificata Suecana Formationis Cambricae. Lunds Universitet Arsskrift, 6:1-14.

668 Toscano-Gadea CA., Costa FG. 2016. Description of the sexual behavior of the Neotropical wolf 669 spider Pavocosa gallopavo (Araneae: Lycosidae), with comments on sexual cannibalism.

670 Journal of Arachnology, 44:412-416.

671 Tschinkel WR. 2003. Subterranean ant nests: Trace fossils past and future? Palaeogeography,

672 Palaeoecology, Palaeoclimatology, 192:321-333.

673 Uchman A, Vrenozi B, Muceku B. 2017. Spider burrows in ichnological context: A review of

674 literature data and burrows of the wolf spider Trochosa hispanica Simon, 1870 from Albania B.

675 Rendiconti Lincei. Scienze Fisiche e Naturali. https://doi.org/10.1007/s12210-017-0662-7.

676 Ungern-Sternberg F. 1876. Salicorniearum Synopsis. Atti del congresso internazionale botanico 
677 tenuto in Firenze nel mese di maggio 1874. 1: 8, Firenze, 259-343.

678 Vrenozi B, Uchman A. 2015. Data on the burrows of the wolf spider Geolycosa vultuosa (C. L.

679 Koch, 1838), the first record for Albania. First International Congress on Continental Ichnology

680 Abstracts, 69-70.

681 Wallace HK. 1942. A revision of the burrowing spiders of the genus Geolycosa (Araneae,

682 Lycosidae). American Midland Naturalist, 27:1-62.

683 White B, Curran HA.1988. Mesoscale physical sedimentary structures and trace fossils in

684 Holocene carbonate eolianites from San Salvador Island, Bahamas. Sedimentary Geology,

685 55:163-184. https://doi.org/10.1016/0037-0738(88)90095-4.

686 Wisshak M, Kroh A, Bertling M, Knaust D, Nielsen JK, Jagt JWM, Neumann C, Nielsen KSS.

687 2015. In defence of an iconic ichnogenus - Oichnus Bromley, 1981. Annales Societatis

688 Geologorum Poloniae, 85:445-451.

689 World Spider Catalog 2017. World Spider Catalog. Natural History Museum Bern. Available at

690 http://wsc.nmbe.ch, version 18.5, (accessed 11 September 2017). DOI 10.24436/2.

691

692 


\section{Figure captions}

694 Figure 1. Compilation of previous descriptions of wolf spider burrows: (A) Geolycosa domifex

695 (Hancock, 1899; fig. P1 II). (B) Generalized shape of spider burrows (Ctenizidae, Antrodiaetidae,

696 Theraphosidae and Lycosidae) from Ratcliffe \& Fagerstrom (1980, fig. 1B). Not to scale. (C)

697 Geolycosa xera archboldi and (D) G. hubbelli burrows by Carrel (2008, fig. 1). (E) Geolycosa

698 missouriensis burrow (Suter et al., 2011, fig. 1). (F) Geolycosa sp. (Chikhale et al., 2013, fig. 7).

699 (G) Allocosa brasiliensis burrows produced by females (a)., males (b), and juveniles (c) (Albín et

700 al. 2015, fig. 1). (H) Hogna lenta: a. vertical shaft (Hils and Hembree ,2015; fig. 12-2), b.

701 vertical shaft with a terminal chamber (Hils and Hembree 2015; fig. 14-4), c. subvertical shaft

702 (Hils and Hembree ,2015; fig. 13-4), and d. Y-shaped burrow (Hils and Hembree ,2015; , fig. 15-

703 1) (I) Tetralycosa (a) offset burrow (b) with original backfilled burrow (Framenau and Hudson,

704 2017, fig. 3). (J) Allocosa senex (Foelix et al., 2017; fig. 16). (K) Trochosa hispanica (Uchman

705 et al., 2017; fig. 6A).

706 Figure 2. Location map of the study area. (A-B) Site of study in the Gran Salitral saline lake in

707 La Pampa Province, Argentina. (C) Geomorphologic map of the Gran Salitral area and location

708 of Pavocosa sp. burrows (GS).

709 Figure 3. Measurements on burrow casts. Length (L), neck length (NL), minimum (mD) and

710 maximum diameter (MD), angle of inclination (A).

711 Figure 4. View of Pavocosa sp. burrows in the field. (A) Site of observation of burrows in an

712 open area with sparse vegetation (Heterostachys ritteriana). (B) Longitudinal section of an

713 inhabited burrow with silk lining. Scale divisions in centimeters. (C) Entrance covered with a

714 thin layer of silk. (D) Burrow partially closed with a cap of silk and sediment pellets; (E) Sac of 
715 eggs found inside the burrow. Scale divisions in millimetres. (F) Partially plugged entrance and

716 sediment pellets dispersed on the surface of the sandflat.

717 Figure 5. Sediments of the sandflat. (A) Detailed section of the sediments observed at the pit. (B)

718 Representative grain size distribution of sediment samples. (C) Classification of sediment

719 samples after Shepard (1954).

720 Figure 6. Comparison between type material of Pavocosa gallopavo and Pavocosa sp. (A)

721 Female epigyne of Pavocosa gallopavo (MACN-Ar 13208), arrow pointing deep furrows on the

722 atrium. (B) Female epigyne of Pavocosa sp. (MACN-Ar 38582), arrow pointing deep furrows on

723 the atrium. (C) Dorsal view of Pavocosa gallopavo (MACN-Ar 13208). (D) Dorsal view of

724 Pavocosa sp. (MACN-Ar 38582). Scale divisions in millimetres.

725 Figure 7. Plaster casts of Pavocosa sp. burrows. (A) GHUNLPam-4771 (Pavocosa sp. Dweller is 726 specimen GHUNLPam -4780). (B) GHUNLPam -4772. (C) GHUNLPam -4773. (Pavocosa sp.

727 dweller and an egg sac found at the bottom of the burrow is specimen GHUNLPam -4770). (D)

728 GHUNLPam -4774. Originally with an egg sac found at the bottom. (E) GHUNLPam -4775. (F-

729 G) Surface texture of burrow casts in the form of sets of two linear parallel ridges (arrows). (H)

730 View of cheliceral fangs of Pavocosa sp. (specimen GHUNLPam -4780).

731 Figure 8. Plaster casts of modified Pavocosa sp. burrows. (A-B) Burrows with umbrella-like

732 structures in the middle part, probably produced by reoccupation by ants (GHUNLPam-4776 and

733 4777). (C-D) Plan view of umbrella-like structure from burrow casts GHUNLPam-4776 and

734 4777. (E) Detail of the knobby surface texture of the umbrella-like structure. (F) Cast showing

735 two smaller burrows arising from the bottom of the wolf spider burrow (GHUNLPam -4778).

736 (G) Funnel-shaped burrow cast as result of predation by a small mammal (GHUNLPam -4779). 
737 Arrows point to a set of two parallel ridges. (H) Detail of the set of two linear parallel ridges

738 (arrows). (I) Field view of burrow modified by predation (related to the cast figured in G). Note 739 brecciated fragments produced during excavation. 


\section{Figure 1}

Compilation of previous descriptions of wolf spider burrows

(A) Geolycosa domifex (Hancock, 1899; fig. PI II). (B) Generalized shape of spider burrows (Ctenizidae, Antrodiaetidae, Theraphosidae and Lycosidae. Ractliffe and Fagerstrom (1980, fig. 1B). Not to scale. (C) Geolycosa xera archboldi and (D) G. hubbelli burrows by Carrel (2008, fig. 1). (E) Geolycosa missouriensis burrow (Suter et al., 2011, fig. 1). (F) Geolycosa sp. (Chikhale et al., 2013, fig. 7); (G) Allocosa brasiliensis: Produced by: a. Females, b. Males, and c. Juveniles (Albín et al. 2015, fig. 1). (H) Hogna lenta: a. vertical shaft (fig. 12-2), b. vertical shaft with a terminal chamber (14-4), c. subvertical shaft (fig. 13-4), and d. Y-shaped burrow (fig. 15-1) (Hils and Hembree ,2015) (I) Tetralycosa (a) offset burrow (b) with original burrow backfilled (Framenau and Hudson, 2017, fig. 3); (J) Allocosa senex (Foelix et al., 2017; fig. 16); (K) Trochosa hispanica (Uchman et al., 2017; fig. 6A). Image credit: Fatima MendozaBelmontes. 


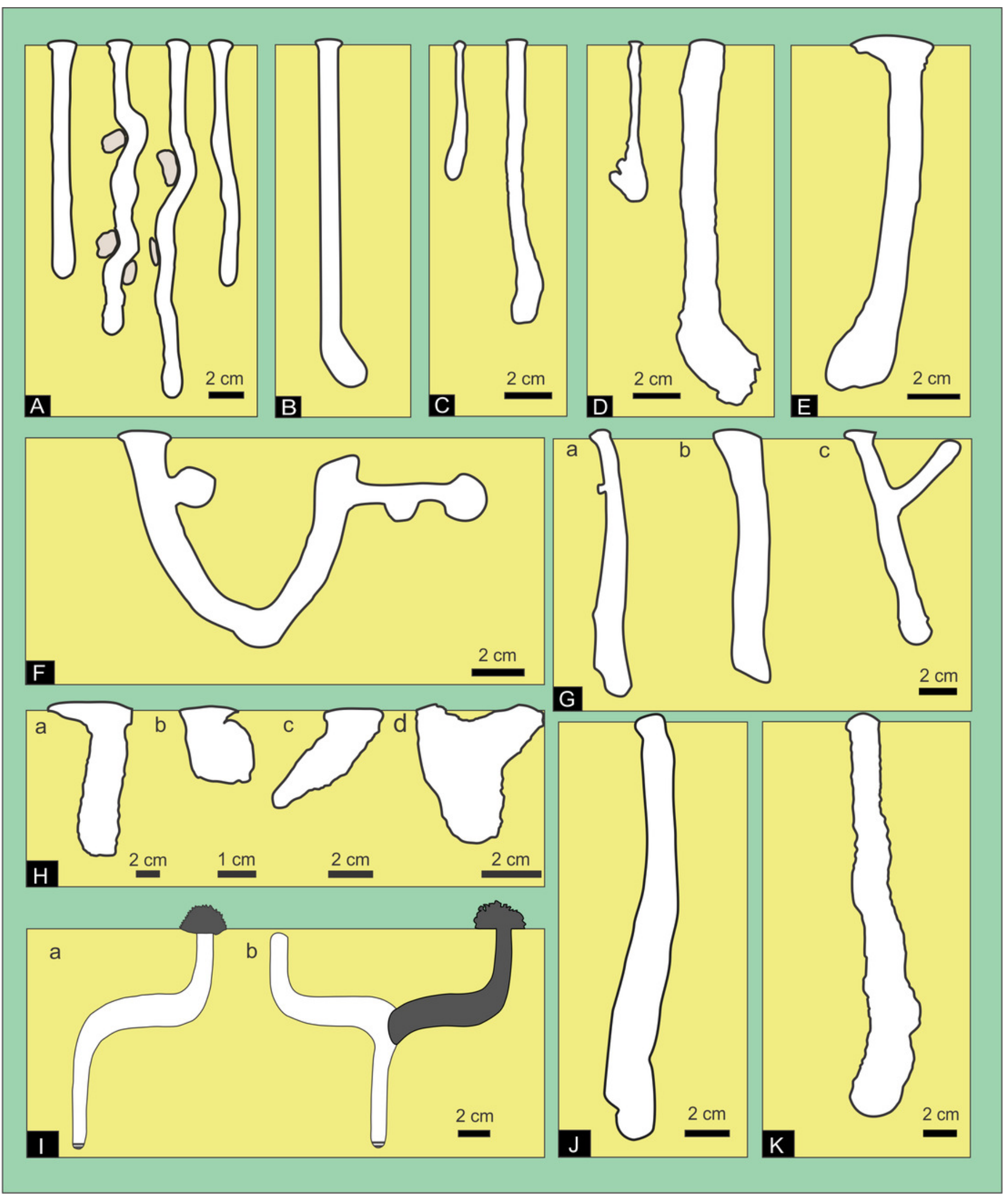


Figure 2

Location map of the study area

(A-B) Site of study in the "Gran Salitral" in La Pampa Province, Argentina; (C)

Geomorphologic map of the Gran Salitral area and location of Pavocosa sp. burrows (GS).

Modified from Melchor et al. (2012). Image credit: Ricardo Melchor. 

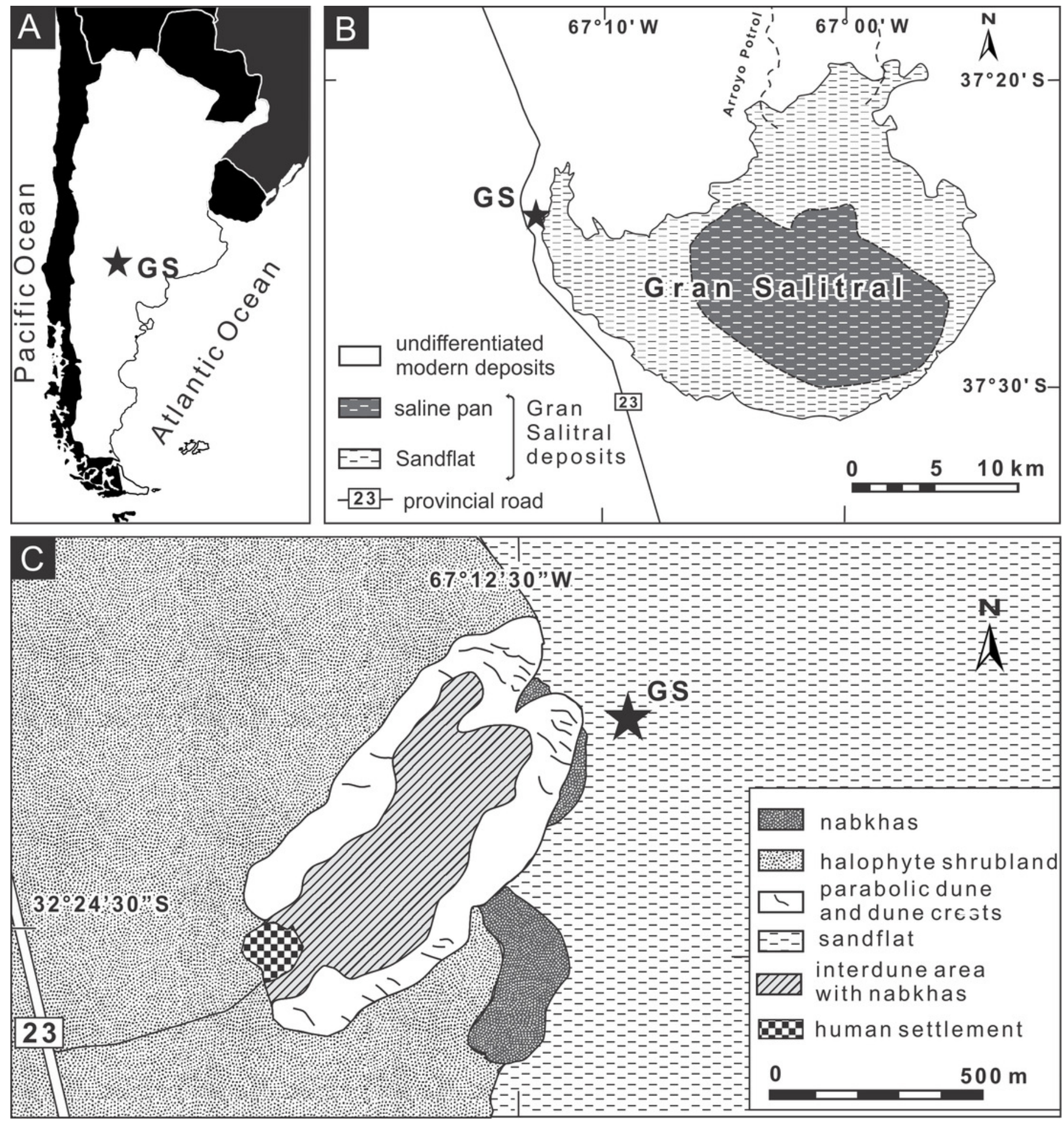


\section{Figure 3}

\section{Measures taken on burrows}

Length (L), neck length (NL), minimum ( $\mathrm{mD}$ ) and maximum diameter (MD), angle of inclination (A). Image credit: Fatima Mendoza-Belmontes. 


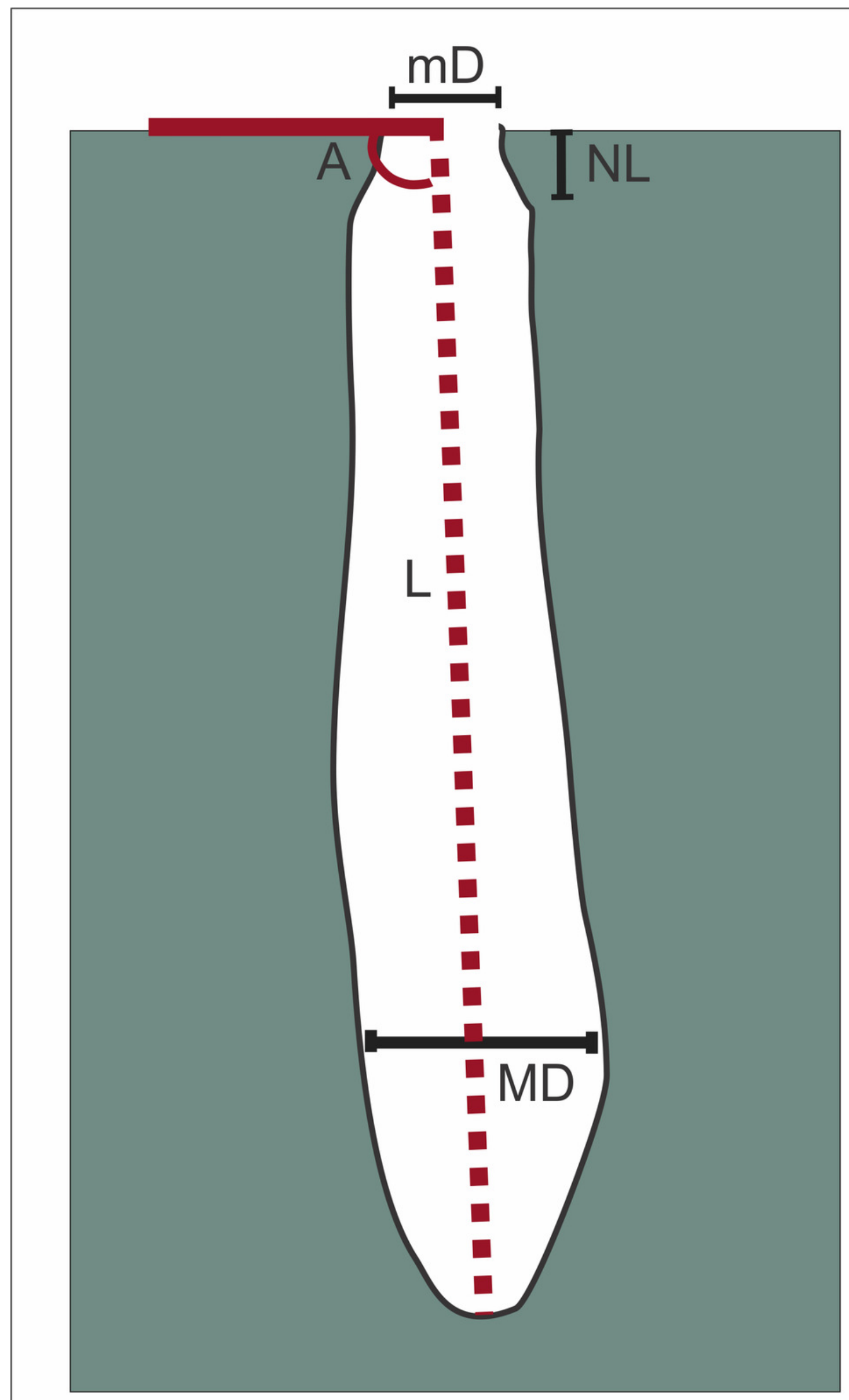




\section{Figure 4}

View of Pavocosa sp. burrows in the field and location.

(A) Site of observation of burrows in an open area with sparse vegetation (Heterostachys ritteriana). (B) Longitudinal section of an inhabited burrow with silk lining. Scale divisions in centimeters. (C) Entrance covered with a thin layer of silk. (D) Burrow partially closed with a cap of silk and sediment pellets; (E) Sac of eggs found inside the burrow. Scale divisions in millimetres. (F) Partially plugged entrance and sediment pellets dispersed on the surface of the sandflat. Photo and image credit: Ricardo Melchor and Fatima Mendoza-Belmontes. 
A

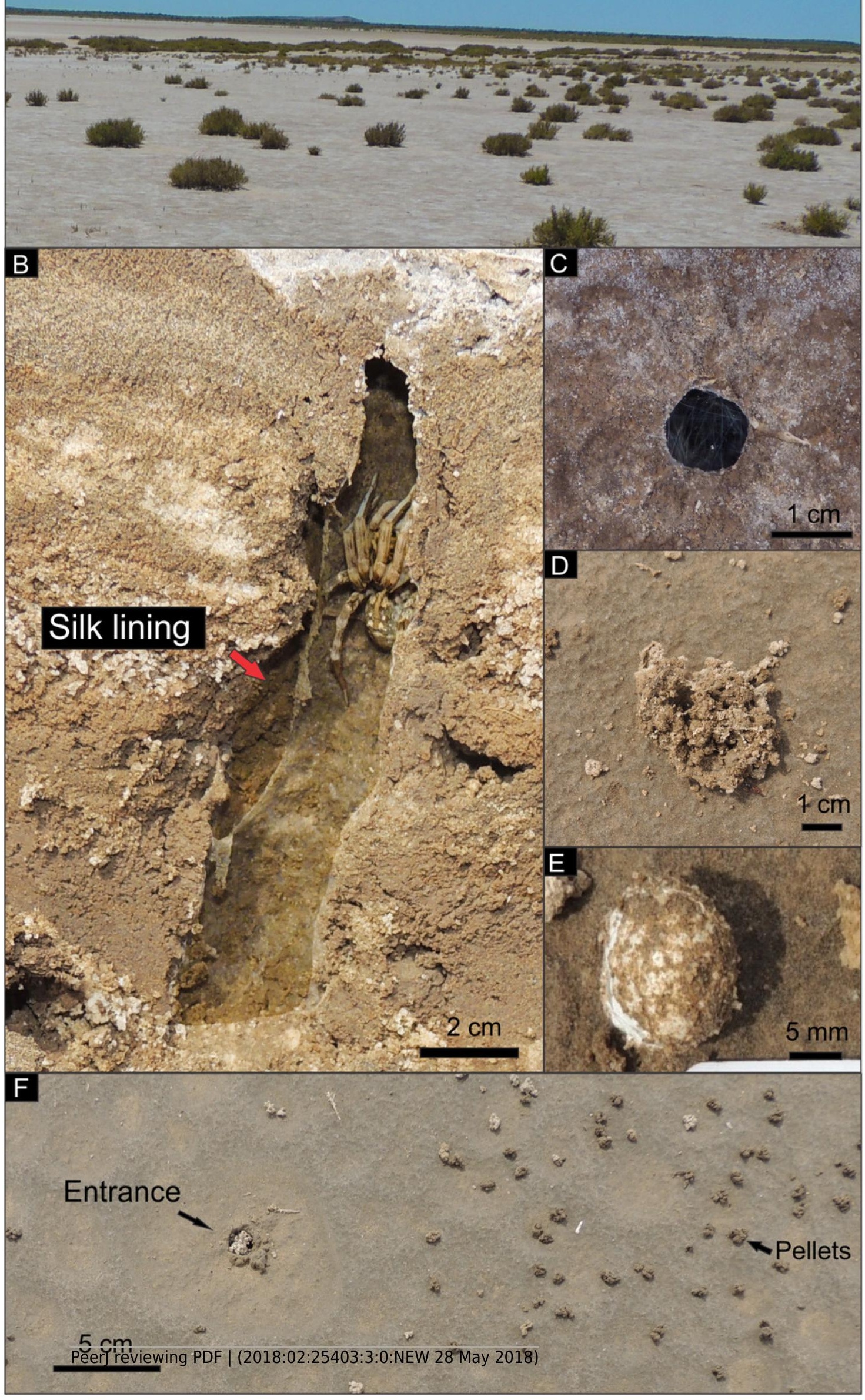


Figure 5

Sediments of the sandflat.

(A) Detailed section of the sediments observed at the pit. (B) Representative grain size distribution of sediment samples. (C) Classification of sediment samples after Shepard (1954). Image credit: Ricardo Melchor and Fatima Mendoza-Belmontes.

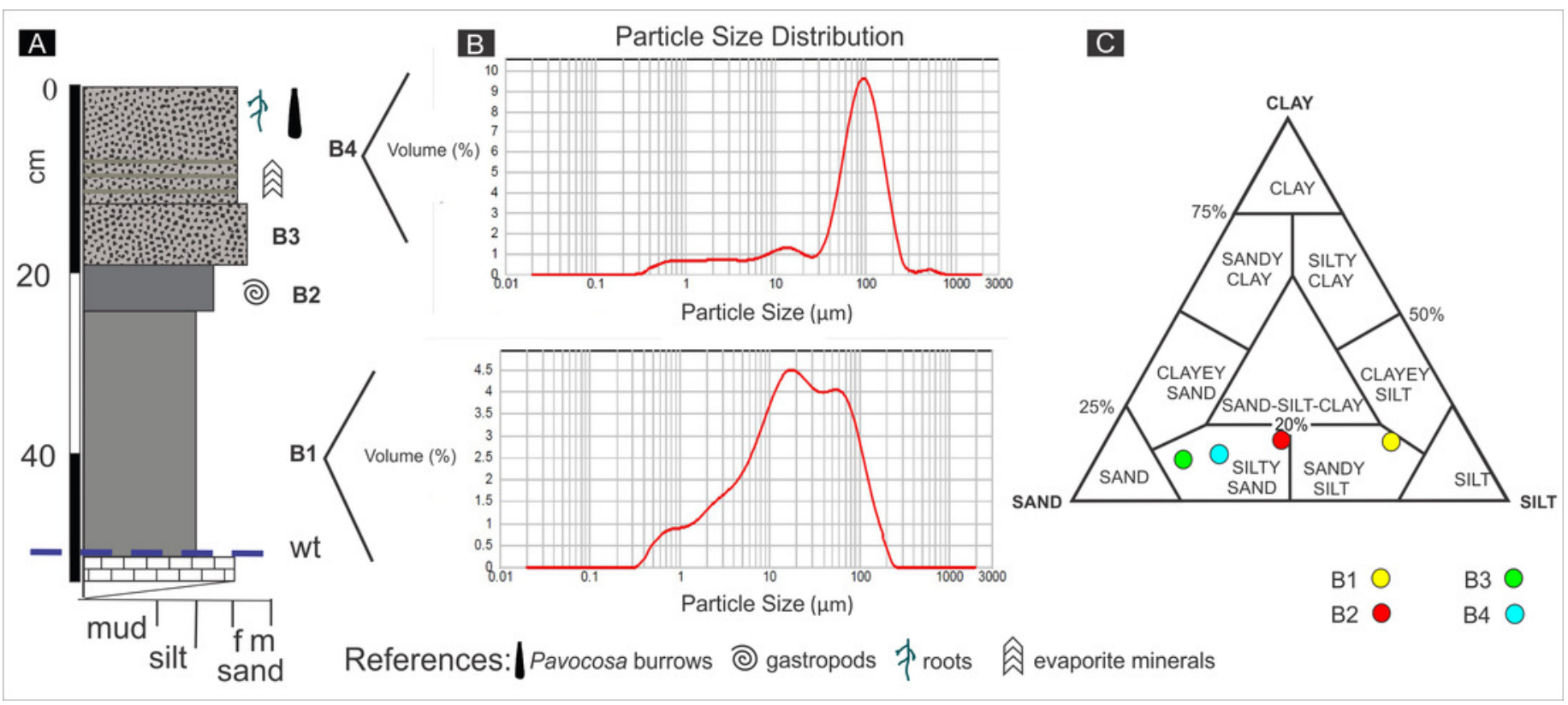




\section{Figure 6}

Comparison between type material of Pavocosa gallopavo and Pavocosa sp.

(A) Female epigyne of Pavocosa gallopavo (MACN-Ar 13208), arrow pointing deep furrows on the atrium. (B) Female epigyne of Pavocosa sp. (MACN-Ar 38582), arrow pointing deep furrows on the atrium. (C) Dorsal view of Pavocosa gallopavo (MACN-Ar 13208). (D) Dorsal view of Pavocosa sp. (MACN-Ar 38582). Scale divisions in millimetres. Image credit: Luis Piacentini. 


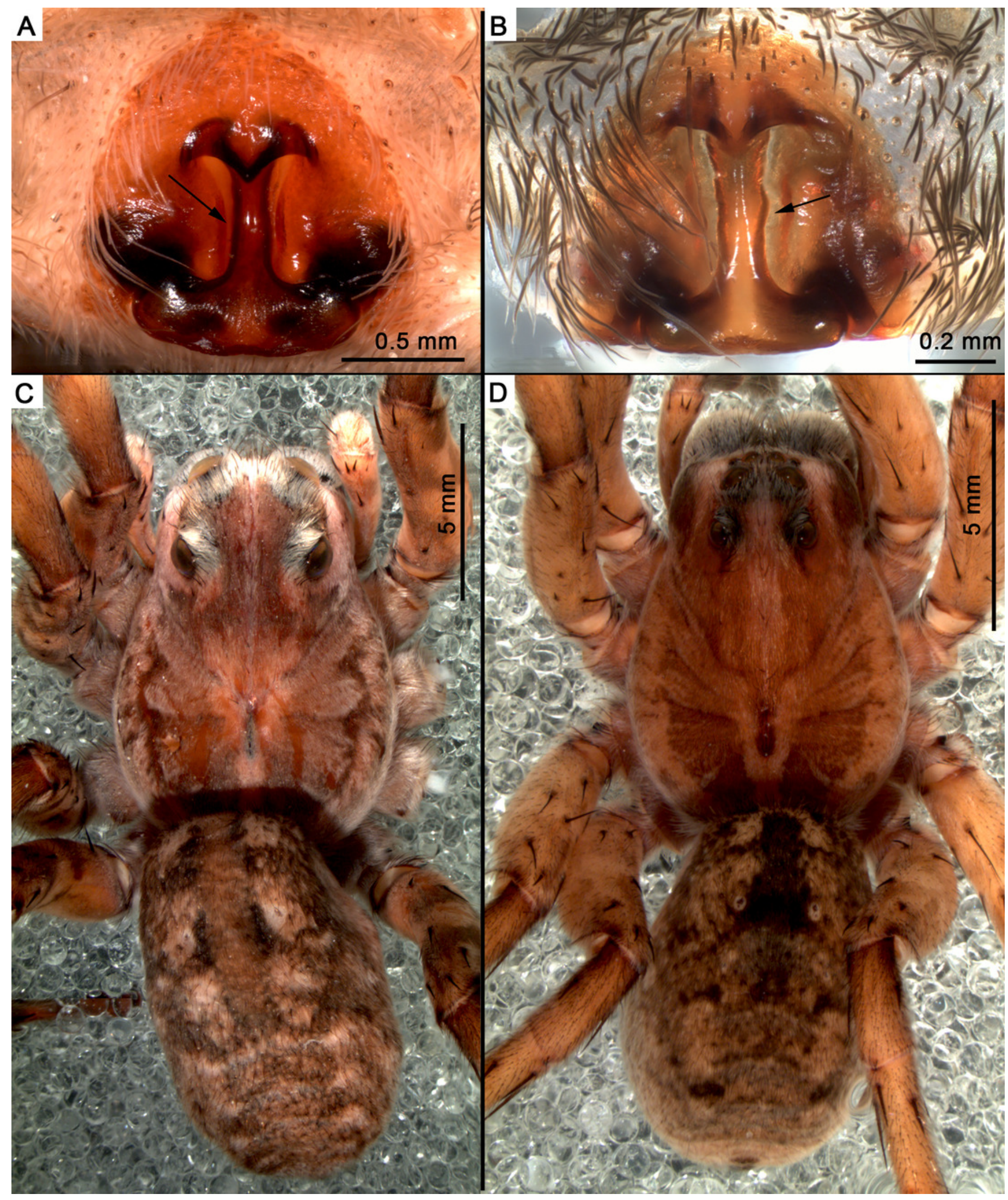




\section{Figure 7}

Plaster casts of Pavocosa sp. burrows.

(A) GHUNLPam-4771. Dweller captured Pavocosa sp. (GHUNLPam -4780). (B) GHUNLPam 4772 (C) GHUNLPam -4773. Dweller captured Pavocosa sp and an egg sac found the bottom (GHUNLPam -4770). (D) GHUNLPam -4774. Egg sac found at the bottom (E) GHUNLPam -4775. (F- G) Surface texture of burrow casts in the form of sets of two linear parallel ridges (arrows) (H) View of cheliceral fangs of Pavocosa sp. (specimen GHUNLPam 4780). Photo and image credit: Fatima Mendoza-Belmontes. 


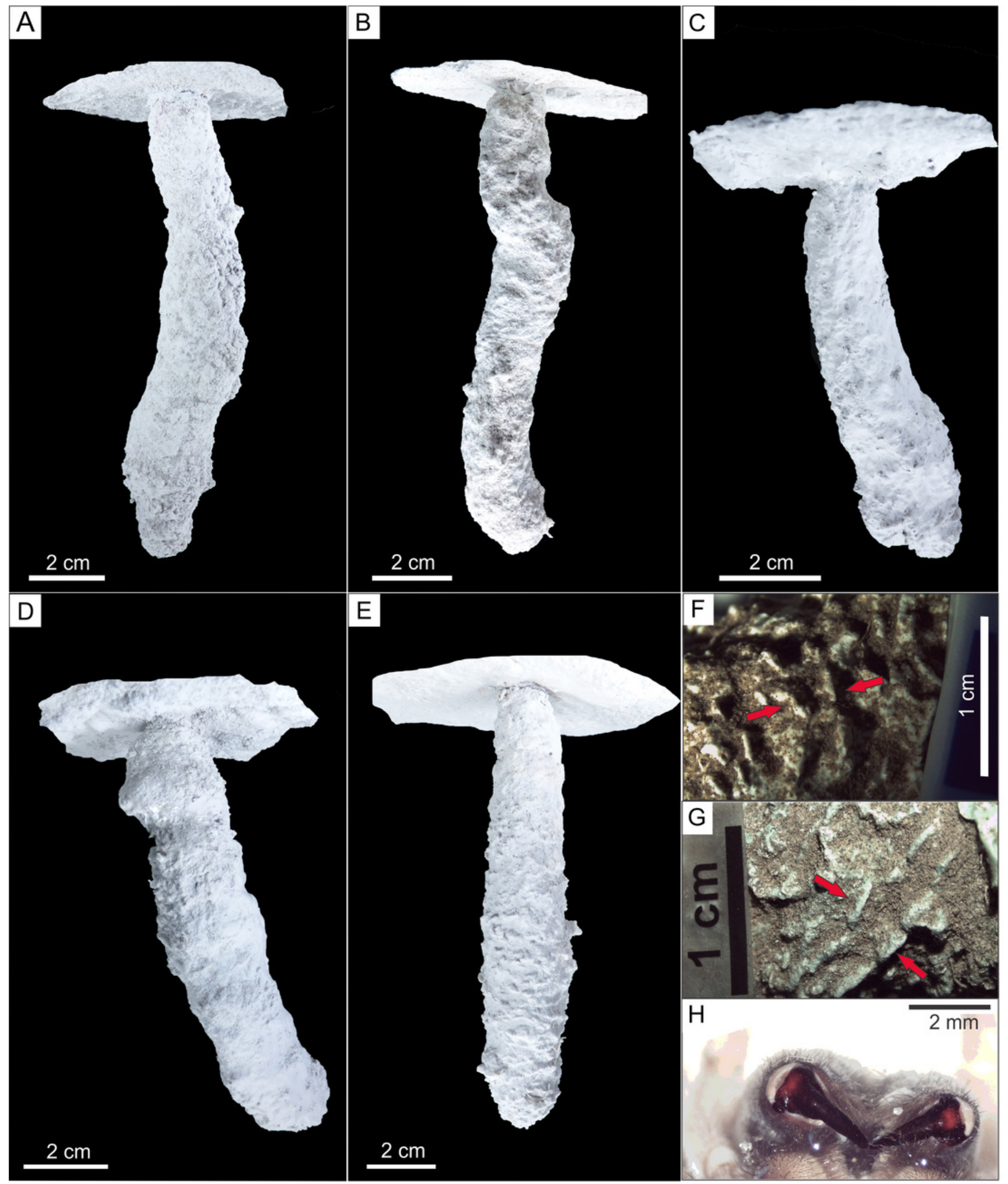




\section{Figure 8}

Plaster casts of modified Pavocosa sp. burrows.

(A-B) Burrows with umbrella-like structures in the middle part, probably produced by reoccupation by ants (GHUNLPam-4776 and 4777). (C-D) Plan view showing umbrella shape from burrow casts GHUNLPam-4776 and 4777. (E) Detail of the knobby surface texture of the umbrella-like structure. (F) Cast showing two smaller burrows arising from the bottom of the wolf spider burrow (GHUNLPam -4778). (G) Funnel-shaped burrow cast as result of predation by a small armadillo (GHUNLPam -4779). Arrows point to set of two parallel ridges. (H) Detail of the set of two linear parallel ridges (arrows). (I) Field view of burrow modified by predation by armadillos (cast figured in $\mathrm{G}$ ). Note brecciated fragments produced during excavation by the armadillo. Photo and image credit: Ricardo Melchor and Fatima Mendoza-Belmontes. 


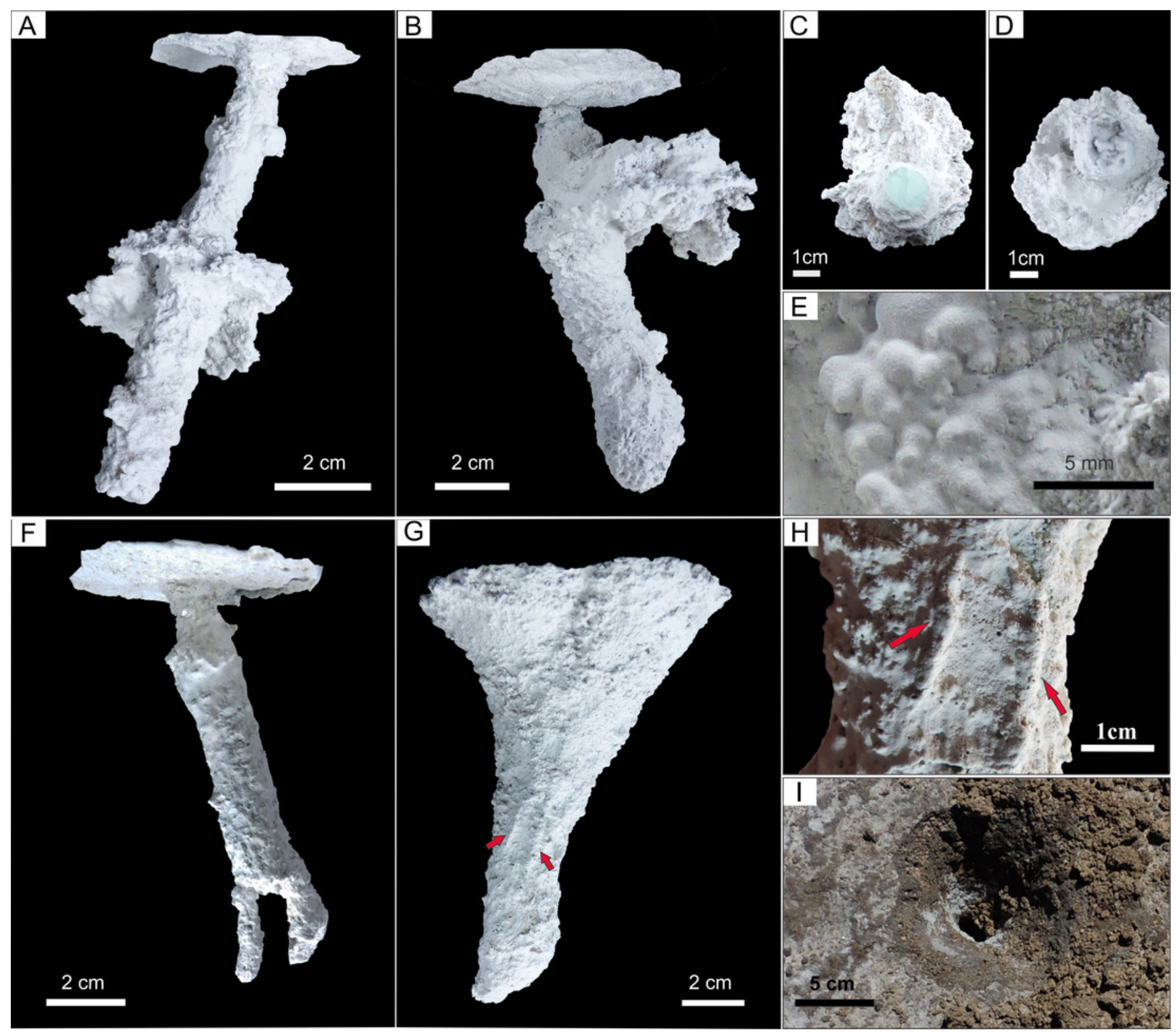

